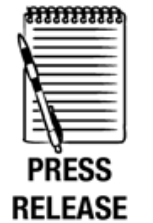

RELEASE

\section{Professional values and reported behaviours of doctors in the USA and UK: quantitative survey}

- An additional appendix is published online only. To view this file please visit the journal online (http:// qualitysafety.bmj.com).

${ }^{1}$ Cambridge Centre for Health Services Research, Institute of Public Health, University of Cambridge, Cambridge, UK ${ }^{2}$ Massachusetts General Hospital, Biostatistics Center and Mongan Institute for Health Policy, Boston, Massachusetts, USA ${ }^{3}$ National Primary Care Research and Development Centre, University of Manchester, Manchester, UK ${ }^{4}$ Centre for Primary Care and Population Research, University of Dundee, The Mackenzie Building, Dundee, UK ${ }^{5}$ Harvard Medical School, Hospital, Mongan Institute for Health Policy, Boston, Massachusetts, USA

Correspondence to Professor Martin Roland, Cambridge Centre for Health Services Research, Institute of Public Health, University of Cambridge, Robinson Way, Cambridge CB2 OSR, UK; mr108@cam.ac.uk

Accepted 20 December 2010 Published Online First 7 March 2011 Massachusetts General

\section{ABSTRACT}

Background: The authors aimed to determine US and UK doctors' professional values and reported behaviours, and the extent to which these vary with the context of care.

Method: 1891 US and 1078 UK doctors completed the survey ( $64.4 \%$ and $40.3 \%$ response rate respectively). Multivariate logistic regression was used to compare responses to identical questions in the two surveys. Results: UK doctors were more likely to have developed practice guidelines ( $82.8 \%$ UK vs $49.6 \%$ US, $p<0.001$ ) and to have taken part in a formal medical errorreduction programme $(70.9 \%$ UK vs $55.7 \%$ US, $p<0.001)$. US doctors were more likely to agree about the need for periodic recertification (completely agree $23.4 \%$ UK vs $53.9 \%$ US, $p<0.001$ ). Nearly a fifth of doctors had direct experience of an impaired or incompetent colleague in the previous 3 years. Where the doctor had not reported the colleague to relevant authorities, reasons included thinking that someone else was taking care of the problem, believing that nothing would happen as a result, or fear of retribution. UK doctors were more likely than US doctors to agree that significant medical errors should always be disclosed to patients. More US doctors reported that they had not disclosed an error to a patient because they were afraid of being sued.

Discussion: The context of care may influence both how professional values are expressed and the extent to which behaviours are in line with stated values.

Doctors have an important responsibility to develop their healthcare systems in ways which will support good professional behaviour.

\section{INTRODUCTION}

\section{C) ULOCKED}

This paper is freely available online under the BMJ Journals unlocked scheme, see http://qualitysafety.bmj. com/site/about/unlocked.xhtml many reasons for this, including the ability of patients to access detailed and accurate information about their own health and illnesses, demonstration of widespread variations in quality of care, well-publicised medical scandals and the rise of managerialism. ${ }^{1}{ }^{2}$ In response to these changes, there have been initiatives in several countries to redefine what it means to be a medical professional, ${ }^{3}$ in some cases advocating a new type of relationship between doctors and their patients-a "new professionalism. ${ }^{4} 5$ These initiatives have produced a number of key documents including a US/European Charter on Medical Professionalism ('the Charter'), ${ }^{6} 7$ 'Doctors in Society' produced by the Royal College of Physicians of London ${ }^{8}$ and statements by the UK General Medical Council including 'Good Medical Practice.'

These statements on professionalism affirm the primacy of patient welfare, avoiding discrimination against patients, and acting with honesty and integrity. They define professional behaviour in terms of avoiding conflicts of interest, providing a high standard of care and engaging in quality improvement activities. All of the documents contain statements about doctors' responsibilities for just distribution of limited medical resources, ensuring fair access to care, and promoting the autonomy of patients. The statements also depart from previous descriptions of professionalism. For example, recent statements emphasise doctors' responsibilities for addressing poor performance by other doctors, with explicit guidance in UK documents that doctors should address unacceptable practice by colleagues. ${ }^{9}$ In addition, self-regulation and professional 
autonomy, once seen as defining features of a profession, are largely absent from recent documents. The British Medical Association, commenting on recent changes in public attitudes to doctors, associates a loss of professional autonomy with a loss of morale among doctors. ${ }^{10}$ However, another study found that doctors generally supported shifts away from paternalism ${ }^{11}$ towards a new type of relationship which Hilton describes as moving from 'priest to mountain guide. ${ }^{12}$

Although statements of professionalism from different countries have much in common, doctors' values and behaviours may be shaped by the context in which they live and work. In this study, we investigated the extent to which current statements of values are supported by doctors working in the different healthcare systems of the UK and USA. These differences include the UK having a nationalised health service with national programmes of standard setting and quality improvement, national bodies to define cost-effectiveness criteria for prescribing drugs, and a payment system under which doctors' income is relatively independent of volume of services provided to patients. We explored the extent to which doctors' reported behaviours were consistent with their stated values and whether differences in reported values and behaviours might be related to differences in the context in which doctors practised.

\section{METHOD}

A survey of professional values previously carried out in the USA in $2003 / 2004^{13}$ was revised and refielded in 2009 alongside a UK survey based on four source documents on professionalism. ${ }^{7-914}$ The questionnaires were designed to permit comparison between the responses of US and UK doctors. We drew random samples of US doctors certified to practise in three primary care specialties (internal medicine, family practice and paediatrics) and four non-primary care specialties (cardiology, general surgery, psychiatry and anaesthesia). In the UK, we drew stratified random samples of trained general practitioners (GPs) and cardiologists, general surgeons and psychiatrists working in England and Scotland. The response rate was $64.4 \%$ in the USA and $40.3 \%$ in the UK. We included weights in the analysis to account for both sampling design and non-response. Analyses reported in this paper were restricted to survey items that were common to both of the US and UK surveys. Multivariate logistic regression models were used to determine the effect of survey country on the different outcomes (values and behaviours) controlling for a range of doctor characteristics. From these models, we obtained adjusted percentages and standard errors which indicate the percentage of respondents in a given category who reported values and behaviours that were in line with the normative statements of professional values. The online appendix contains further details of the development and delivery of the questionnaire and statistical methods used.

\section{RESULTS}

Table 1 summarises doctors' characteristics. We adjusted for these in subsequent multivariate analyses which are shown in table 2 (reported values) and table 3 (reported behaviours).

The great majority of doctors supported the normative values expressed in the documents on which the two surveys were based. Likewise, the majority of behaviours

Table 1 Comparison between US and UK respondents

\begin{tabular}{|c|c|c|c|c|c|c|}
\hline Variable & Category & $\begin{array}{l}\text { Percentage USA } \\
\left(n=1289^{\star}\right)\end{array}$ & SE & $\begin{array}{l}\text { Percentage UK } \\
(n=1078 \dagger)\end{array}$ & SE & p Value \\
\hline \multirow[t]{2}{*}{ Gender } & Female & 30.4 & 1.51 & 38.1 & 2.64 & 0.0111 \\
\hline & Male & 69.7 & 1.51 & 61.9 & 2.64 & \\
\hline \multirow[t]{4}{*}{ Years in practice } & $<10$ & 12.5 & 1.09 & 8.8 & 1.66 & 0.008 \\
\hline & $10-19$ & 27.4 & 1.48 & 25.2 & 2.33 & \\
\hline & $20-29$ & 30.1 & 1.47 & 42.1 & 2.69 & \\
\hline & $\geq 30$ & 30.0 & 1.44 & 23.9 & 2.31 & \\
\hline \multirow[t]{4}{*}{ Specialty } & General/family practice & 68.1 & 0.17 & 84.1 & 0.00 & $<0.0001$ \\
\hline & Cardiology & 8.7 & 0.04 & 1.8 & 0.00 & \\
\hline & Psychiatry & 13.6 & 0.07 & 9.8 & 0.00 & \\
\hline & General Surgery & 9.7 & 0.05 & 4.3 & 0.00 & \\
\hline $\begin{array}{l}\text { Country of } \\
\text { graduation }\end{array}$ & $\begin{array}{l}\text { Graduated from medical } \\
\text { school in the country of survey } \\
\text { (USA/Canada/UK) }\end{array}$ & 71.0 & 1.49 & 81.4 & 2.08 & $<0.001$ \\
\hline Full-time working & $\geq 40 \mathrm{~h} /$ week & 73.8 & 1.42 & 57.0 & 2.67 & $<0.001$ \\
\hline
\end{tabular}


Table 2 Comparison of US and UK doctors' responses to value statements

\begin{tabular}{|c|c|c|c|c|}
\hline Value statement & $\begin{array}{l}\text { Country } \\
\text { of survey }\end{array}$ & $\begin{array}{l}\text { Adjusted percentages } \\
\text { (strongly agreeing } \\
\text { with statement) }\end{array}$ & SE & p Value \\
\hline \multicolumn{5}{|l|}{$\begin{array}{l}\text { Making the patient your first concern, avoiding conflicts } \\
\text { of interest }\end{array}$} \\
\hline Doctors should put patients' welfare above the doctor's & USA & 78.7 & 1.37 & \multirow{2}{*}{0.1932} \\
\hline own financial interests & UK & 82.3 & 2.23 & \\
\hline Doctors should disclose their financial relationships & USA & 65.4 & 1.58 & \multirow[t]{2}{*}{0.0465} \\
\hline with drug/medical device companies to their patients & UK & 58.9 & 2.76 & \\
\hline \multicolumn{5}{|l|}{$\begin{array}{l}\text { Providing good care, commitment to improving care, } \\
\text { keeping up to date }\end{array}$} \\
\hline Doctors should participate in peer review of the & USA & 54.9 & 1.67 & \multirow[t]{2}{*}{$<0.0001$} \\
\hline $\begin{array}{l}\text { quality of care provided by colleagues-for example, } \\
\text { by reviewing their records }\end{array}$ & UK & 68.4 & 2.61 & \\
\hline Doctors should undergo periodic recertification & USA & 53.9 & 1.66 & \multirow[t]{2}{*}{$<0.0001$} \\
\hline examinations throughout their career. & UK & 23.4 & 2.44 & \\
\hline \multicolumn{5}{|l|}{$\begin{array}{l}\text { Taking action (including relevant reporting) to deal with } \\
\text { colleagues' poor performance }\end{array}$} \\
\hline Doctors should report all instances of significantly & USA & 63.1 & 1.61 & \multirow[t]{2}{*}{0.2601} \\
\hline $\begin{array}{l}\text { impaired or incompetent colleagues to relevant } \\
\text { authorities }\end{array}$ & UK & 59.3 & 2.82 & \\
\hline \multicolumn{5}{|l|}{$\begin{array}{l}\text { Maintaining confidentiality of information about patients } \\
\text { and their conditions }\end{array}$} \\
\hline Doctors should never disclose confidential patient & USA & 91.1 & 0.97 & \multirow[t]{2}{*}{0.0026} \\
\hline health information to an unauthorised individual & UK & 96.3 & 0.99 & \\
\hline \multicolumn{5}{|l|}{$\begin{array}{l}\text { Being truthful to patients and to colleagues, including } \\
\text { when things go wrong }\end{array}$} \\
\hline Doctors should disclose all significant medical errors & USA & 63.5 & 1.64 & \multirow[t]{2}{*}{0.0384} \\
\hline to patients who have been affected & UK & 70.2 & 2.57 & \\
\hline Doctors should fully inform all patients of the benefits & USA & 88.4 & 1.07 & \multirow[t]{2}{*}{$<0.0001$} \\
\hline and risks of a procedure or course of treatment & UK & 73.8 & 2.44 & \\
\hline Doctors should never tell a patient something that & USA & 83.2 & 1.24 & \multirow[t]{2}{*}{0.387} \\
\hline is not true (assuming the patient is competent) & UK & 85.3 & 1.94 & \\
\hline \multicolumn{5}{|l|}{ Avoiding inappropriate relationships with patients } \\
\hline Joint business ventures with patients are 'never & USA & 46.7 & 1.62 & \multirow[t]{2}{*}{$<0.0001$} \\
\hline appropriate' & UK & 60.0 & 2.69 & \\
\hline Sexual relationships with patients are 'never & USA & 92.1 & 0.92 & \multirow[t]{2}{*}{0.8174} \\
\hline appropriate' & UK & 91.7 & 1.53 & \\
\hline Accepting modest gifts from patients or patients' & USA & 11.5 & 1.06 & \multirow[t]{2}{*}{0.0426} \\
\hline families is 'never appropriate' & UK & 7.2 & 1.6 & \\
\hline \multicolumn{5}{|l|}{$\begin{array}{l}\text { Avoiding discrimination-for example, on grounds of } \\
\text { race and creed }\end{array}$} \\
\hline Doctors should minimise disparities in care due to & USA & 84.2 & 1.21 & \multirow[t]{2}{*}{0.0569} \\
\hline patient race, gender or income & UK & 88.7 & 1.82 & \\
\hline
\end{tabular}

Values adjusted for country differences in gender, years since qualification, specialty, country of graduation and part-time working Home graduate: graduate from a medical school in the country of survey (USA/Canada or UK).

Working full time: $\geq 40 \mathrm{~h} /$ week.

which might be regarded as running counter to professional values were reported infrequently. Where such behaviours were reported, doctors were more likely to say that they happened 'sometimes' rather than 'often.'

Almost all doctors reported that they had changed their practice in the previous 3 years as a result of familiarising themselves with a practice guideline $(95.5 \%$ UK, $93.1 \%$ USA, $\mathrm{p}=0.14$ ), though UK doctors were much more likely to have participated in the development of practice guidelines $(82.8 \%$ UK vs $49.6 \%$ US, $\mathrm{p}<0.001)$.
Doctors were less positive in their support for quality improvement activities. UK doctors were more likely to agree that they should participate in peer review of care provided by their colleagues (completely agree: $68.4 \%$ UK vs $54.9 \%$ US, $\mathrm{p}<0.001$ ) but only just over half had taken part in reviewing another doctor's records for the purpose of quality improvement ( $54.5 \%$ UK vs $55.0 \%$ US, $\mathrm{p}=0.88$ ). UK doctors were much more likely to report that they had taken part in a formal medical error reduction programme ( $70.9 \%$ UK vs $55.7 \%$ US, $\mathrm{p}<0.001$ ), but US doctors were 
Table 3 Comparison of US and UK doctors' reported behaviours

\begin{tabular}{|c|c|c|c|c|}
\hline Behaviour (all in past year except where indicated) & Country & $\begin{array}{l}\text { Adjusted } \\
\text { percentage } \\
\text { replying 'Yes' }\end{array}$ & SE & p Value \\
\hline \multicolumn{5}{|l|}{ Making the patient your first concern, avoiding conflicts of interest } \\
\hline Have you received any gifts/samples from drug, device or other & USA & 83.3 & 1.27 & \multirow[t]{2}{*}{0.0002} \\
\hline medically related companies (past year)? Percentage replying 'Yes.' & UK & 73.2 & 2.52 & \\
\hline \multicolumn{5}{|l|}{ Providing good care, commitment to improving care, keeping up to date } \\
\hline Have you changed your practice after familiarising yourself with & USA & 93.1 & 0.83 & \multirow[t]{2}{*}{0.1436} \\
\hline $\begin{array}{l}\text { a practice guideline relevant to your field (past } 3 \text { years)? Percentage } \\
\text { replying 'Yes.' }\end{array}$ & UK & 95.5 & 1.18 & \\
\hline Have you participated in a formal medical error reduction initiative in & USA & 55.7 & 1.66 & \multirow[t]{2}{*}{$<0.0001$} \\
\hline $\begin{array}{l}\text { your office, clinic, hospital or other healthcare setting (past } 3 \text { years)? } \\
\text { Percentage replying 'Yes.' }\end{array}$ & UK & 70.9 & 2.42 & \\
\hline Have you participated in the development of formal clinical practice & USA & 49.6 & 1.67 & \multirow[t]{2}{*}{$<0.0001$} \\
\hline guidelines (past 3 years)? Percentage replying 'Yes.' & UK & 82.8 & 2 & \\
\hline Have you reviewed another doctor's medical records for the purpose & USA & 55.0 & 1.66 & \multirow[t]{2}{*}{0.8807} \\
\hline of quality improvement (past 3 years)? Percentage replying 'Yes.' & UK & 54.5 & 2.73 & \\
\hline \multicolumn{5}{|c|}{ Taking action (including relevant reporting) to deal with colleagues' poor performance } \\
\hline Have you had direct personal knowledge of a doctor who was impaired & USA & 16.5 & 1.23 & \multirow[t]{2}{*}{0.3839} \\
\hline $\begin{array}{l}\text { or incompetent to practise medicine in your hospital or practice? } \\
\text { Percentage replying 'Yes' in past } 3 \text { years. }\end{array}$ & UK & 18.7 & 2.14 & \\
\hline In the most recent case, did you report that doctor to a hospital, clinical, & USA & 65.3 & 3.77 & \multirow[t]{2}{*}{0.2944} \\
\hline professional society or other relevant body? Percentage replying 'Yes.' & UK & 72.7 & 5.7 & \\
\hline In the most recent case did you have a personal discussion with that & USA & 59.7 & 3.88 & \multirow[t]{2}{*}{0.3923} \\
\hline doctors about his/her problems? Percentage replying 'Yes.' & UK & 65.9 & 5.79 & \\
\hline In the most recent case did you stop referring your patients to that & USA & 72.4 & 3.7 & \multirow[t]{2}{*}{$<0.0001$} \\
\hline doctor? Percentage replying 'Yes.' & UK & 17.2 & 5.01 & \\
\hline In the most recent case did you not report the doctor because you were & USA & 12.4 & 2.5 & \multirow[t]{2}{*}{0.1717} \\
\hline $\begin{array}{l}\text { afraid of retribution? Percentage replying 'Yes' (for doctors who had } \\
\text { experience of an impaired colleague and decided not to report them). }\end{array}$ & UK & 34.2 & 20.23 & \\
\hline In the most recent case did you not report the doctor because you & USA & 20.1 & 3.18 & \multirow[t]{2}{*}{0.6993} \\
\hline $\begin{array}{l}\text { though someone else was taking care of the problem? Percentage } \\
\text { replying 'Yes' (for doctors who had experience of an impaired colleague } \\
\text { and decided not to report them). }\end{array}$ & UK & 25.7 & 15.09 & \\
\hline In the most recent case did you not report the doctor because you & USA & 15.9 & 2.74 & \multirow[t]{2}{*}{0.8297} \\
\hline $\begin{array}{l}\text { believed that nothing would happen as a result? Percentage replying } \\
\text { 'Yes' (for doctors who had experience of an impaired colleague and } \\
\text { decided not to report them). }\end{array}$ & UK & 14.3 & 6.38 & \\
\hline \multicolumn{5}{|c|}{$\begin{array}{l}\text { Respecting patients' autonomy to choose between appropriate courses of clinical action and/or decline investigations } \\
\text { or treatments }\end{array}$} \\
\hline Have you prescribed a brand name drug when a generic was available & USA & 18.8 & 1.27 & \multirow[t]{2}{*}{0.2972} \\
\hline $\begin{array}{l}\text { because the patient asked for the brand name drug specifically? } \\
\text { Percentage replying 'Never.' }\end{array}$ & UK & 21.4 & 1.95 & \\
\hline Have you given a patient a referral to a specialist because the patient & USA & 16.7 & 1.11 & \multirow[t]{2}{*}{0.1023} \\
\hline $\begin{array}{l}\text { wanted it when you believed it was not indicated? Percentage } \\
\text { replying 'Never.' }\end{array}$ & UK & 13.2 & 1.61 & \\
\hline \multicolumn{5}{|l|}{ Maintaining confidentiality of information about patients and their conditions } \\
\hline Have you intentionally or unintentionally revealed to an unauthorised & USA & 71.3 & 1.51 & \multirow[t]{2}{*}{0.1181} \\
\hline $\begin{array}{l}\text { person health information about one of your patients? Percentage } \\
\text { replying 'Never.' }\end{array}$ & UK & 75.9 & 2.37 & \\
\hline \multicolumn{5}{|c|}{ Being truthful to patients and to colleagues, including when things go wrong } \\
\hline Have you told an adult patient or child's guardian something that was & USA & 89.4 & 1.05 & \multirow[t]{2}{*}{0.014} \\
\hline not true? Percentage replying 'Never.' & UK & 94.1 & 1.3 & \\
\hline Have you not fully disclosed a mistake to a patient because you were & USA & 21.4 & 1.37 & \multirow[t]{2}{*}{0.0017} \\
\hline afraid of being sued? Percentage replying 'Never.' & UK & 12.7 & 1.99 & \\
\hline \multicolumn{5}{|l|}{ Avoiding inappropriate relationships with patients } \\
\hline Have you provided direct patient care for a person with whom you have & USA & 8.7 & 0.94 & \multirow[t]{2}{*}{$<0.001$} \\
\hline a financial relationship? & UK & 0.8 & 0.42 & \\
\hline
\end{tabular}




\begin{tabular}{|c|c|c|c|c|}
\hline Behaviour (all in past year except where indicated) & Country & $\begin{array}{l}\text { Adjusted } \\
\text { percentage } \\
\text { replying 'Yes' }\end{array}$ & SE & p Value \\
\hline \multicolumn{5}{|l|}{ Avoiding discrimination-for example on grounds of race or creed } \\
\hline \multirow{2}{*}{$\begin{array}{l}\text { Have you refused to provide medical services or give information } \\
\text { about medical services based on your religious beliefs (past } 3 \text { years)? } \\
\text { Percentage replying 'Never.' }\end{array}$} & USA & 94.9 & 0.76 & \multirow{2}{*}{0.1431} \\
\hline & UK & 97.0 & 0.98 & \\
\hline \multirow{2}{*}{$\begin{array}{l}\text { Have you provided health-related expertise to local community } \\
\text { organisations-for example school boards, parent-teaching } \\
\text { organisations, athletic teams or local media (past } 3 \text { years)? }\end{array}$} & USA & 40.9 & 1.63 & \multirow[t]{2}{*}{0.0002} \\
\hline & UK & 29.1 & 2.51 & \\
\hline \multicolumn{5}{|l|}{ Percentage replying 'Yes.' } \\
\hline \multirow{2}{*}{$\begin{array}{l}\text { Have you looked for data on possible disparities in care due to race, } \\
\text { gender or income in your practice, clinic, hospital or other healthcare } \\
\text { setting (past } 3 \text { years)? Percentage replying 'Yes.' }\end{array}$} & USA & 12.4 & 1.1 & \multirow[t]{2}{*}{0.4373} \\
\hline & UK & 14.1 & 1.96 & \\
\hline
\end{tabular}

much more likely to agree about the need for periodic recertification examinations compared with UK doctors (23.4\% UK vs $53.9 \%$ US, $\mathrm{p}<0.001)$.

UK doctors were less likely that those in the US to agree that all the benefits and risks of a procedure should be explained to the patient ('completely agree' UK $73.8 \%$ vs $88.4 \%$ US $\mathrm{p}<0.001)$. However, when things went wrong, UK doctors were significantly more likely than their US counterparts to agree that significant medical errors should always be disclosed to affected patients (completely agree $70.2 \%$ UK vs $63.5 \%$ US, $\mathrm{p}=0.04$ ). More US doctors reported that they had not disclosed an error to a patient at some time in the previous year because they were afraid of being sued (12.7\% UK vs $21.4 \%$ US, $\mathrm{p}=0.002$ ).

Sixty per cent of doctors in both countries agreed with the statement that in all instances significantly impaired or incompetent colleagues should be reported to relevant authorities (completely agree $59.3 \% \mathrm{UK}$, $63.1 \%$ US, $\mathrm{p}=0.26$ ). Nearly a fifth of doctors had experience of an impaired or incompetent colleague in the previous 3 years $(18.7 \% \mathrm{UK}, 16.5 \%$ US, $\mathrm{p}=0.38)$, and over two-thirds of these had reported this colleague to relevant authorities $(72.7 \% \mathrm{UK}, 65.3 \% \mathrm{US}, \mathrm{p}=0.29)$. The commonest action taken by US doctors with knowledge of an impaired or incompetent colleague was to stop referring patients to that doctor-an action much less commonly reported by UK doctors $(17.2 \%$ UK, $72.4 \%$ US, $\mathrm{p}<0.001)$. Where doctors had not reported an impaired colleague to the authorities, the commonest reasons given were because they thought someone else was taking care of the problem $(25.7 \%$ UK, $20.1 \%$ US, $\mathrm{p}=0.70)$, because they were afraid of retribution $(34.2 \% \mathrm{UK}, 12.4 \% \mathrm{US}, \mathrm{p}=0.17)$, or because they thought nothing would happen $(14.3 \% \mathrm{UK}, 15.9 \%$ US, $\mathrm{p}=0.83)$.
Doctors in both countries endorsed statements supporting patient autonomy. Few doctors had declined to prescribe a branded drug when the patient asked for it $(21.4 \% \mathrm{UK}, 18.8 \% \mathrm{US}, \mathrm{p}=0.30)$ or had not agreed to a patient's request for a specialist referral even when the doctor did not think the referral was indicated $(13.2 \%$ UK, $16.7 \%, \mathrm{p}=0.10)$. These are examples of areas where different values may conflict-for example, behaviours associated with encouraging patient autonomy may conflict with those that promote delivery of the most cost effective care.

Doctors from both countries agreed that they should minimise disparities in care due to race, gender or religion (completely agree $88.7 \%$ UK vs $84.2 \% \mathrm{US}, \mathrm{p}=0.06$ ), though fewer than one-fifth of doctors in either country had actually looked at data on health inequalities in their practice $(14.1 \%$ US vs $12.4 \%$ US, $\mathrm{p}=0.44)$.

In terms of conflicts of interest, UK doctors were more likely than those in the US to consider business relationships with patients as 'never appropriate' $(60.0 \%$ UK vs $46.7 \%$ US, $\mathrm{p}<0.001$ ), and less likely to have provided care for someone with whom they had a financial relationship $(0.8 \%$ UK, $8.7 \%$ US $\mathrm{p}<0.001)$. While the majority agreed that doctors should put the patient's welfare above their own financial interest, support was not universal (completely agree $82.3 \%$ UK, 78.7\% US). The majority of doctors in both countries had received gifts from pharmaceutical companies in the previous year, though less commonly in the UK than in the USA (73.2\% UK vs $83.3 \%$ US, p<0.001).

\section{DISCUSSION}

The study suggests that doctors in the USA and UK generally give strong support for the values espoused by their professional bodies, though with some important 
differences in both values and reported behaviours. Some of these may reflect differences in the organisation and management of healthcare in the two countries. For example, over $90 \%$ of doctors in both countries reported that their behaviour had been altered by clinical guidelines in the previous 3 years, but doctors in the UK were much more likely to have participated in the development of clinical guidelines. In another survey, UK primary care physicians were more likely to report that they routinely used written guidance in clinical practice. ${ }^{15}$ These differences may reflect the greater acceptance by UK doctors of standardised approaches to care articulated by UK bodies such as the National Institute for Health and Clinical Excellence (http://www.nice. org.uk/), while comparative effectiveness research remains controversial in the USA. ${ }^{15}$

More than twice as many UK as US primary care physicians reported in the recent Commonwealth Fund survey that they routinely received and reviewed data on patient care. ${ }^{15}$ In our survey, only just over half of both UK and US doctors had actually taken part in peer review of a colleague's records in the previous 3 years, but UK doctors were more likely to endorse the value of peer review of their colleagues' medical records and more likely to have participated in a formal error reduction programme. Doctors in the US however were more than twice as likely to endorse the need for periodic recertification compared with doctors in the UK. These differences may reflect familiarity with the systems in which doctors are used to working, with systematic programmes of quality improvement having been rolled out across the UK National Health Service over the last 10 years, ${ }^{16}$ but recertification (or revalidation) yet to be developed in the UK while being common in the USA.

In our survey, nearly a fifth of doctors in both the USA and UK had direct personal experience of an impaired or incompetent colleague in the previous 3 years but onethird in both countries had not reported this colleague to a relevant authority. Of these, over half had talked to the doctor about their problem, and more than $20 \%$ had not reported the doctor because they thought someone else was dealing with the problem. However, $34 \%$ of UK doctors did not report their colleague because they were afraid of retribution, possibly reflecting unsympathetic treatment of 'whistleblowers' which has been widely reported in the British medical press. ${ }^{17}{ }^{18}$ Indeed, in a recent British Medical Association survey, $16 \%$ of doctors who had reported a concern about a member of staff said they were told that by speaking up, their employment could be negatively affected. ${ }^{19}$ In contrast to doctors from the UK, the commonest action reported by US doctors faced with an impaired colleague was to stop referring to that doctor-a course of action not always open to UK doctors working within a more constrained healthcare system.
The great majority of doctors in both countries thought that medical errors should be discussed with affected patients, but US doctors were more than twice as likely as their UK counterparts not to have disclosed an error because they were afraid of being sued, possibly reflecting the different malpractice environment in which US patients are much more likely to sue their doctors. ${ }^{20}$ This difference may also account for the greater likelihood of US doctors agreeing that all risks and benefits of interventions should be explained to patients.

It was perhaps surprising that only $80 \%$ of doctors in the two countries strongly agreed with the statement that 'Doctors should put patients' welfare above the doctor's own financial interests.' Our results suggest that US doctors were more accepting of potential conflicts of interest: they were more likely to believe that business relationships were appropriate, more likely to report actual business relationships with patients and more likely to receive gifts from pharmaceutical companies.

The study is limited in a number of respects. First, only four medical specialties are presented in this paper, and other specialties may respond differently. Second, the response rate among UK doctors was low (40.3\%); the US survey may have achieved higher response rates $(64.4 \%)$ due to the provision of a financial incentive and telephone follow-up of non-responders. The limited analyses that we were able to carry out did not suggest that non-response bias was a major issue in the UK sample, and in all our analyses we used weights that accounted for non-response in order to reduce potential bias. Third, there may have been social desirability bias from doctors being reluctant to report values or behaviours which they knew were out of line with stated professional norms, so we cannot tell how far the behaviours reported in this survey relate to actual behaviours in clinical practice.

Despite these limitations, our results strongly suggest that there is a significant core of professional values which is common across the two countries, but that the national context of care may influence both how those values are expressed and the support which doctors give them. Behaviours may be shaped by external factors that influence whether doctors seek to, or are able to, behave in ways consistent with their professional values. We believe that as well as promoting high standards of behaviour from within their own professional societies, it is important for doctors to advocate for healthcare system reforms that facilitate high standards of behaviour. Medical leadership in the UK National Health Services has been described as 'conspicuous by its absence, ${ }^{11}$ and a recent report calls on doctors to assume more active roles in defining the future characteristics of their profession. ${ }^{21}$ Especially at times of major healthcare reform, as both the USA and UK currently 
face, doctors have an important responsibility to develop their healthcare systems in ways which will support good professional behaviour.

Acknowledgements We are grateful to the Nuffield Trust who funded the UK survey, to the ABIM Foundation who part-funded the US survey and to the Institute on Medicine as a Profession who funded the US survey and provided financial support for focus groups held in the UK during the development of the questionnaire.

Funding Nuffield Trust, Institute on Medicine as a Profession.

Competing interests None.

Provenance and peer review Not commissioned; externally peer reviewed.

\section{REFERENCES}

1. Harrison S, Ahmad WIU. Medical autonomy and the UK state 1975 to 2025. Sociology 2000;34:129-46.

2. McKinlay JB, Marceau LD. The end of the golden age of doctoring. Int J Health Serv 2002:32:379-416.

3. Chisholm A, Askham J. A Review of Codes and Standards for Doctors in the UK, USA and Canada. Oxford: Picker Institute Europe, 2006. http://www.pickereurope.org/item/document/59 (accessed 18 Jan 2011).

4. Irvine D. The performance of doctors: the new professionalism. Lancet 1999;353:1174-7.

5. Rothman D. Medical Professionalism-focusing on the real issues. N Engl J Med 2000;342:124-6.

6. ABIM Foundation. American Board of Internal Medicine; ACP-ASIM Foundation. American College of Physicians-American Society of Internal Medicine; European Federation of Internal Medicine. Medical professionalism in the new millennium: a physician charter. Ann Intern Med 2002;136:243-6.

7. Medical Professionalism Project. Medical professionalism in the new millennium: a physicians' charter. Lancet 2002;359:520-2.
8. Royal College of Physicians. Doctors in Society: Medical Professionalism in a Changing World. Report of a Working Party of the Royal College of Physicians of London. London: RCP, 2005.

9. General Medical Council. Duties of a Doctor, 2009. http://www.gmcuk.org/guidance/good_medical_practice/duties_of_a_doctor.asp (accessed 13 Nov 2009).

10. British Medical Association. Professional Values: Findings from BMA Cohort Studies. London: British Medical Association, 2008.

11. Levenson R, Dewar S, Shepherd S. Understanding Doctors: Harnessing Professionalism. London: Kings Fund, 2008.

12. Hilton $\mathrm{S}$. Education and the changing face of medical professionalism: from priest to mountain guide? $\mathrm{Br} J$ Gen Pract 2008;58:353-61.

13. Campbell EG, Regan S, Gruen RL, et al. Professionalism in medicine: results of a national survey of physicians. Ann Intern Med 2007; 137:795-802

14. Anon. Medical Schools Council: Consensus Statement on the Role of the Doctor. London, 2008. http://www.medschools.ac.uk/AboutUs/ Projects/Documents/Role\%20of\%20Doctor\%20Consensus\% 20Statement.pdf (accessed 18 Jan 2011).

15. Mushlin Al, Ghomrawi $\mathrm{H}$. Health care reform and the need for comparative-effectiveness research. N Engl J Med 2010;362:e6.

16. Buetow S, Roland M. Clinical governance: bridging the gap between managerial and clinical approaches to improving quality of care. Qual Health Care 1999;8:184-90.

17. Gooderham P. Changing the face of whistleblowing. BMJ 2009;338: b2090.

18. Gornall J. The price of silence. BMJ 2009;339:b3202

19. Anon. British Medical Association Health Policy and Economic Research Unit. Speaking up for Patients. London: British Medical Association, 2009. http://www.bma.org.uk/ethics/doctor relationships/whistleblowingsurvey.jsp (accessed 28 Jun 2010).

20. Kessler DP, Summerton N, Graham JR. Effects of the medical liability system in Australia, the UK, and the USA. Lancet 2006;368:240-6.

21. Royal College of Physicians. Future Physician: Changing Doctors in Changing Times. London: Royal College of Physicians of London, 2010.

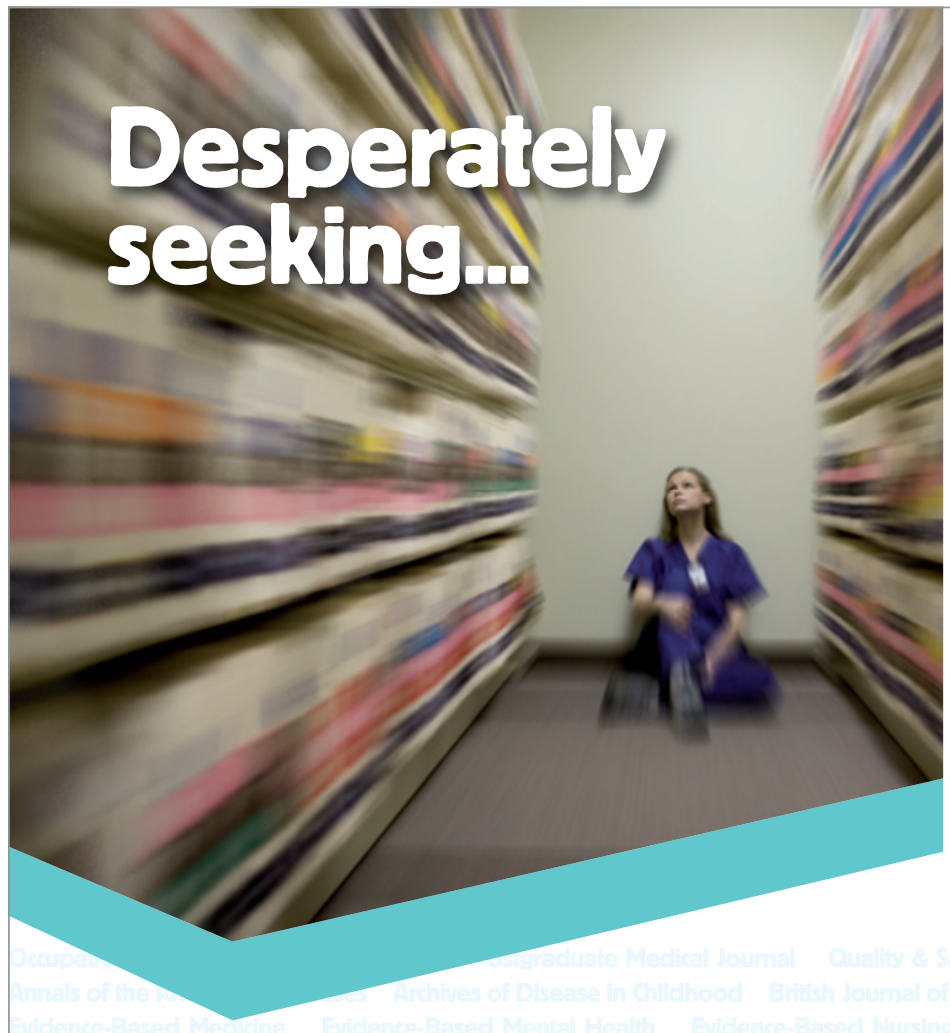

\section{...an old article?}

The full back archive is now available for all of BMJ Journals in a diverse range of specialties. Subscribers may access the entire archive without registration. Non-subscribers have FREE access to all articles prior to 2006, right back to volume 1, issue 1 .

A simple one-time registration needs to be completed to access the archive http://journals.bmj.com/cgi/register

The online archives were digitised with the help of the National Library of Medicine. 